\title{
PREVALENCE OF FOOT DEFORMITIES IN YOUNG SCHOOLCHILDREN IN SLAVONIA
}

\author{
Irella Bogut ${ }^{1}, \check{Z}$ eljko Popović $^{1}, Z_{\text {vonimir Tomac }}^{1,2}$, Valentina Matijević ${ }^{3}$ and Goranka Radmilović ${ }^{4}$ \\ ${ }^{1}$ Department of Natural Sciences, Faculty of Education, Josip Juraj Strossmayer University of Osijek, Osijek, Croatia; \\ ${ }^{2}$ Department of Social Sciences, Faculty of Education, Josip Juraj Strossmayer University of Osijek, Osijek, Croatia; \\ ${ }^{3}$ Department of Rheumatology, Physical Medicine and Rehabilitation, \\ Sestre milosrdnice University Hospital Centre, School of Medicine, University of Zagreb, \\ Zagreb and Faculty of Medicine in Osijek, Josip Juraj Strossmayer University of Osijek, Osijek, Croatia; \\ ${ }^{4}$ Daruvarske Toplice Special Hospital for Medical Rehabilitation, Daruvar, Croatia
}

\begin{abstract}
SUMMARY - The aim of this study was to determine the occurrence of foot deformity in urban children, as well as possible generational and gender differences using graphic and angular methods. The sample of study subjects included $4261^{\text {st }}$ to $4^{\text {th }}$ grade schoolchildren (7 to 10 years of age). Out of the total number of schoolchildren, 181 children ( 88 boys and 93 girls) were measured in 2005, and 244 children (122 boys and 123 girls) in 2011. The results indicated that the largest number of children had no noticeable foot deformity, flat foot in particular. Likewise, there were no gender differences in the occurrence of flat foot and no statistically significant differences in the incidence between the children measured in 2005 and 2011. Due to the problems that foot deformities could cause, it is necessary to continue monitoring foot arches of young schoolchildren in order to intervene on time and prevent the occurrence of deformities by appropriate therapeutic procedures.
\end{abstract}

Key words: Foot deformities; Flatfoot; Child; Urban population; Croatia

\section{Introduction}

The foot is the last part of the lower extremity kinetic chain. As such, it has two basic tasks in terms of stability and dynamics of motion. The complex structure, shaped like a double lever, provides support when standing and moving, and allows adjustment to the unevenness of the ground ${ }^{1}$. The stability and dynamics of foot are rendered possible through the transverse and two longitudinal foot arches which, according to Oatis ${ }^{2}$ play a role in protecting the muscles, nerves and blood vessels of the plantar aspect of the foot under load, but they also render possible the absorption of force during collision with the surface, as well as pro-

Correspondence to: Prof. Željko Popović, MS, Department of Natural Sciences, Faculty of Education, Josip Juraj Strossmayer University of Osijek, Cara Hadrijana 10, HR-31000 Osijek, Croatia E-mail: popovic@foozos.hr

Received September 25, 2017, accepted December 4, 2017 duction and release of energy during locomotion. Foot arch indexes indicate the amount of foot contact with the surface and their development.

Thus, in a healthy foot, the medial longitudinal arch is elevated 15 to $18 \mathrm{~mm}$ from the surface, while the lateral arch is elevated 3 to $5 \mathrm{~mm}$ from the surface ${ }^{3}$. Deformities occur if the above-mentioned ratio of foot arches is disrupted, whereby the abnormal foot height, which exceeds $18 \mathrm{~mm}$, causes pes cavus, whereas the significantly reduced foot height causes pes planus ${ }^{2}$. Although all three arches functionally support the foot, it has been established that the medial longitudinal arch has clinical significance in both diseases and, ultimate$l y$, it has an effect on the functioning of the muscles and joints of the ankle, knee, hip, and of the lower back $^{4}$. Muscle weakness, bone abnormalities, excessive body weight, inherited weakness of supportive tissue, excessive physical effort, prolonged standing, bad habits during standing and walking, and unsuitable foot- 
wear disrupt the complicated texture (architectonics) of the foot and the foot arch begins to lower whereby causing flat foot ${ }^{5}$.

Flat foot is a deformity of modern humans, the consequence of still incomplete adaptation to the upright position of walking on two legs. In primitive communities, as well as in poor regions, where people mostly walk barefoot or wear light leather footwear, there are no cases of flat foot. In such people, all muscles and joints are constantly active because, while walking, the foot constantly adjusts to uneven ground conditions. It is precisely foot deformities that cause further problems of the musculoskeletal apparatus, not just of the foot joints but along the entire locomotor system.

It is wrong to think that pain in the flat foot begins and remains only in the foot. As the first sign of 'foot flattening', patients can feel pain in the calves, lower back and upper back. The pain originates from stretched joint connections (ligaments); patients can feel weight in the legs and they can quickly get tired during walking. Afterwards, strong pain in the legs, the back, and even in the head may occur; they are the consequence of strain, of 'stretching' the numerous muscles by which the body attempts to change posture or walk, in an unconscious intention to reduce pain in the foot. Sometimes the first changes on the foot are noticed on the heel, which turns to the outside and foot pronation develops as compensation.

Afterwards, first the longitudinal medial arch begins to lower, followed by the lateral and eventually the transverse arch. In addition to foot pronation, shortening of the muscles of the peroneal group also occurs, as well as sensitivity of the plantar fascia and yielding of supporting structures of the medial side of the foot and tibialis posterior tendon ${ }^{4}$. When the arches irreversibly get lowered, the foot becomes longer, wider in the front, shoes become too narrow and too short. Walking is associated with pain and tiredness. In severe cases, due to constant and strong pressure on the numerous bones of the foot, severe deformity of the foot occurs, which is associated with unbearable pain when moving and standing ${ }^{5}$.

The problem of foot deformity occurs very frequently ${ }^{6}$, and manifests in a high percentage and much more frequently than other deformities of the locomotor system. These deformities cause significant postural deviations and other health problems, not only in adults but also in the adolescent population. Videmsek et al. ${ }^{7}$ established flat foot already in 3-year-old children in $72 \%$ of cases, $20 \%$ were borderline cases, and the feet were healthy only in $8 \%$ of cases. However, development of foot arches takes place in childhood, most intensively up to year 3, and it is considered that the development of foot arches ends approximately with the development of walk, approximately by year 12 in both genders when it ends in girls, while the critical period for the development of plantar arch is up to year $6^{8}$.

Thus, flat foot is more common in younger children, somewhat less common in older children, and rarely occurs in adults ${ }^{9}$. The so-called flexible flat foot often appears in childhood as well, which is in fact normal foot shape and is present in a large percentage of the population. Flexible flat foot may occur due to the still undeveloped foot arches in children, but also due to shortened Achilles tendon, which causes pain and disability in some adolescents and adults, in which cases surgical treatment is indicated ${ }^{10}$. In the research by Garcia-Rodriguez et al. ${ }^{11}$ on a sample of children aged 4 to 13 , it was found that as many as $75 \%$ of total flat feet appeared at the age of 4 and 5, while AbdelFattah et al. ${ }^{9}$ found only $5 \%$ of flat feet in a sample of soldiers aged 18-21.

Therefore, Rose ${ }^{12}$ points out that one should be cautious when making conclusion about the occurrence of foot deformity in childhood because the percentage may be overestimated as the foot development is not yet complete. Although flat feet are a physiological phase in the first decade of life and are corrected spontaneously, one needs to be cautious because advancement of untreated abnormally developed feet can result in structural changes of the skeleton and lower limb joints causing escalating pain ${ }^{13}$. Mikic et al. ${ }^{14}$ in a sample of 166 children aged 8 to 9 found that $65 \%$ and $68 \%$ of the subjects were free from deformities on any foot. First-degree deformity was found in $20 \%-21 \%$ and $2^{\text {nd }}$ degree deformity in $7 \%-10 \%$ of the subjects, whereas only $3.85 \%$ of the subjects suffered from $3^{\text {rd }}$ degree deformity. In children of the mean age of 9.23 , El et al..$^{15}$ found almost $83 \%$ of healthy feet and only $17 \%$ of moderately flexible flat foot. Results observed by Thomasen method in a sample of young football players aged 11 to 13 showed very different values, where only $37 \%$ of the subjects had healthy left foot and $34 \%$ had healthy right foot. First degree flat foot 
was recorded in 50\%-60\% of cases, whereas second and third degrees were found in 3\%-10\% of cases ${ }^{16}$. Similar results have also been reported by Kendic et al. ${ }^{17}$ in a sample of 552 schoolchildren of the $1^{\text {st }}, 2^{\text {nd }}$ and $4^{\text {th }}$ grades; in girls, depending on their age, deformities occurred in 60\%-66\% of cases, with an average frequency of almost $65 \%$, whereas the incidence among boys ranged between $52 \%$ and $65 \%$, with an average frequency of $62 \%$. The problem with the diagnosis of flat foot is not only the age of subjects, but the literature often brings into question diagnostic methods as well, particularly regarding the reliability of measuring instruments ${ }^{18,19}$. When determining the degree of foot deformity, orthopedists apply three types of methods: graphic, angular and indexing methods. Mayer's method and the modified method of Russian authors are the most commonly used graphic methods. The best-known angular method is Clarke's method, while Irwing index, Chippaux-Smirak index and Cavanagh index are among the best-known indexing methods ${ }^{20}$. This research was conducted with the objective to determine the occurrence of foot deformity in urban children, as well as the possible generational and gender differences using graphic and angular methods.

Table 1. Sample description

\begin{tabular}{|c|c|c|c|c|}
\hline & & Grade & $\mathrm{n}$ & $\%$ \\
\hline \multirow{8}{*}{ 능 } & \multirow{4}{*}{ M } & 1 & 30 & 34.1 \\
\hline & & 2 & 22 & 25.0 \\
\hline & & 3 & 13 & 14.8 \\
\hline & & 4 & 23 & 26.1 \\
\hline & \multirow{4}{*}{$\mathrm{F}$} & 1 & 27 & 29.0 \\
\hline & & 2 & 25 & 26.9 \\
\hline & & 3 & 20 & 21.5 \\
\hline & & 4 & 21 & 22.6 \\
\hline \multirow{8}{*}{ 궁 } & \multirow{4}{*}{$\mathrm{M}$} & 1 & 19 & 15.6 \\
\hline & & 2 & 30 & 24.6 \\
\hline & & 3 & 28 & 23.0 \\
\hline & & 4 & 45 & 36.9 \\
\hline & \multirow{4}{*}{$\mathrm{F}$} & 1 & 29 & 23.6 \\
\hline & & 2 & 24 & 19.5 \\
\hline & & 3 & 29 & 23.6 \\
\hline & & 4 & 41 & 33.3 \\
\hline
\end{tabular}

$\mathrm{M}=$ male $\mathrm{F}=$ female $; \mathrm{n}=$ number of students

\section{Subjects and Methods}

\section{Sample of subjects}

The sample of study subjects included $4261^{\text {st }}$ to $4^{\text {th }}$ grade schoolchildren aged 7-10 years (Table 1). Out of the total number of study schoolchildren, 181 of them ( 88 boys and 93 girls) were measured in 2005, and 244 children (122 boys and 123 girls) in 2011.

\section{Data collection}

Data were collected during physical education classes at school, so that schoolchildren stepped barefoot at normal walking pace into a shallow bowl filled with paint and then stepped out and made a footprint on the paper. Data on school, grade, age and gender of each child were previously recorded on the paper. After collecting the samples, foot prints were analyzed.

The degree of foot deformity was determined by two methods, graphic Mayer's and angular Clark's method. Mayer's method was carried out by drawing a line from the middle of the heel print towards the inner edge of the fourth toe (Fig. 1). If the width of the print of the middle narrow section of the foot exceeds the so-called Mayer's line on the inside, the person has a lowered arch. Mayer's method reveals deformity in the initial phase ${ }^{20}$.

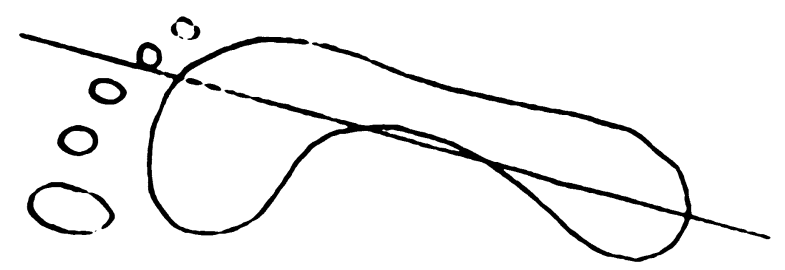

Fig. 1. Mayer's method ${ }^{20}$.

Clark's method determines the footprint angle $(\alpha)$ between the line connecting the inner point of the heel and the front part of the footprint $(\mathrm{A}-\mathrm{A})$, and the line

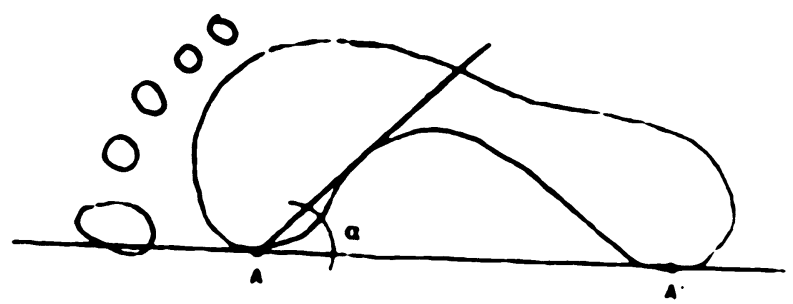

Fig. 2. Clark's method ${ }^{20}$. 
connecting the most convex point of the inner edge of the footprint (A-B) (Fig. 2). In normal foot, the angle is over 42 degrees, and in flat foot the angle is less than 42 degrees ${ }^{20}$.

\section{Statistics}

For each individual subsample, the frequency and percentage of subjects in each category were calculated (healthy foot, $1^{\text {st }}$ degree deformity, $2^{\text {nd }}$ degree deformity and $3^{\text {rd }}$ degree deformity). The $\chi^{2}$-test was used to determine differences in each category according to age, gender and years.

\section{Results and Discussion}

Analyzing differences in deformity frequencies between the two measurements by $\chi^{2}$-test $\left(\chi^{2}=8.48\right.$; $\mathrm{p}=0.21$, no statistically significant differences were observed when comparing 2005 and 2011. There were no statistically significant differences in the frequency of deformity either in boys $\left(\chi^{2}=6.53 ; p=0.25\right)$ or in girls $\left(\chi^{2}=6.98 ; \mathrm{p}=0.32\right)($ Table 2$)$.

In 2005 , there were no significant gender differences in the frequency of foot deformity $\left(\chi^{2}=9.77\right.$; $\mathrm{p}=0.76)$ and the same applied to $2011 \quad\left(\chi^{2}=2.61\right.$; $\mathrm{p}=0.76$ ) (Table 2).

In 2005, deformity frequencies in the total sample were not significantly different $\left(\chi^{2}=21.73 ; p=0.24\right)$. By analyzing differences separately for each gender, there were no statistically significant differences in the frequencies according to age either in boys $\left(\chi^{2}=23.82\right.$; $\mathrm{p}=0.06)$ (Table 3$)$, or in girls $\left(\chi^{2}=17.36 ; \mathrm{p}=0.29\right)$ measured in the same year (Table 4).

As in the first measurement, in 2011 there were no significant differences according to age in the total sample $\left(\chi^{2}=11.51 ; \mathrm{p}=0.71\right)$ (Table 1$)$, in boys $\left(\chi^{2}=13.49\right.$; $\mathrm{p}=0.33)$ (Table 5), and in girls $\left(\chi^{2}=7.67 ; \mathrm{p}=0.81\right)$ either (Table 6).

Study results demonstrated that the highest percentage of children had no noticeable foot deformity, thus $76.24 \%$ of children in 2005 and $75.92 \%$ of children in 2011 had healthy feet (Table 1). The only noticeable percentage of children with foot deformity referred to $1^{\text {st }}$ degree flat foot category, with $9.39 \%$ in 2005 and $14.69 \%$ in 2011. There were no significant differences in the occurrence of foot deformity either between the 2005 and 2011 generations or according to gender and age between and within each subsample (Table 1).

The results of this research indicated that the largest number of children aged 7-11 had no noticeable foot deformities, thus in children measured in 2005 and 2011 the frequency of deformity was about $76 \%$. The only noticeable percentage of children with foot deformity referred to $1^{\text {st }}$ degree flat foot category, with $9.39 \%$ in 2005 and $14.69 \%$ in 2011 (Table 1). There

Table 2. Foot deformity frequencies in 2005 and 2011

\begin{tabular}{|c|c|c|c|c|c|c|c|c|c|c|c|c|}
\hline & \multicolumn{6}{|c|}{2005} & \multicolumn{6}{|c|}{2011} \\
\hline & \multicolumn{2}{|l|}{ All } & \multicolumn{2}{|l|}{$\mathrm{M}$} & \multicolumn{2}{|l|}{$\mathrm{F}$} & \multicolumn{2}{|l|}{ All } & \multicolumn{2}{|l|}{ M } & \multicolumn{2}{|l|}{$\mathrm{F}$} \\
\hline & $f$ & $\%$ & $f$ & $\%$ & $f$ & $\%$ & $f$ & $\%$ & $\mathrm{f}$ & $\%$ & $\mathrm{f}$ & $\%$ \\
\hline Healthy foot & 138.00 & 76.24 & 61.00 & 69.32 & 77.00 & 82.80 & 186.00 & 75.92 & 93.00 & 76.23 & 93.00 & 75.61 \\
\hline $\begin{array}{l}\text { Pes planus } \\
1^{\text {st }} \text { degree }\end{array}$ & 17.00 & 9.39 & $1 ., 00$ & 12.50 & 6.00 & 6.45 & 36.00 & 14.69 & 1.00 & 15.57 & 17.00 & 13.82 \\
\hline $\begin{array}{l}\text { Pes planus } \\
2^{\text {nd }} \text { degree }\end{array}$ & 11.00 & 6.08 & 8.00 & 9.09 & 3.00 & 3.23 & 12.00 & 4.90 & 6.00 & 4.92 & 6.00 & 4.88 \\
\hline $\begin{array}{l}\text { Pes planus } \\
3^{\text {rd }} \text { degree }\end{array}$ & 5.00 & 2.76 & 4.00 & 4.55 & 1.00 & 1.08 & 1.00 & 0.41 & 1.00 & 0.82 & 0.00 & 0.00 \\
\hline $\begin{array}{l}\text { Pes cavus } \\
1^{\text {st }} \text { degree }\end{array}$ & 8.00 & 4.42 & 3.00 & 3.41 & 5.00 & 5.38 & 8.00 & 3.27 & 3.00 & 2.46 & 5.00 & 4.07 \\
\hline $\begin{array}{l}\text { Pes cavus } \\
2^{\text {nd }} \text { degree }\end{array}$ & 1.00 & 0.55 & 1.00 & 1.14 & 1.00 & 1.08 & 1.00 & 0.41 & 0.00 & 0.00 & 1.00 & 0.81 \\
\hline $\begin{array}{l}\text { Pes cavus } \\
3^{\text {rd }} \text { degree }\end{array}$ & 1.00 & 0.55 & 0.00 & 0.00 & 1.00 & 1.08 & 0.00 & 0.00 & 0.00 & 0.00 & 0.00 & 0.00 \\
\hline
\end{tabular}

$\mathrm{M}=$ male $\mathrm{F}=$ female; $\mathrm{f}=$ frequency 
Table 3. Foot deformity frequencies in boys in 2005

\begin{tabular}{|l|l|l|l|l|l|l|l|l|l|}
\hline & \multicolumn{2}{|l|}{$1^{\text {st }}$ grade } & \multicolumn{2}{l|}{$2^{\text {nd }}$ grade } & \multicolumn{2}{|l|}{$3^{\text {rd }}$ grade } & \multicolumn{2}{|l|}{$4^{\text {th }}$ grade } \\
\cline { 2 - 10 } & $\mathrm{f}$ & $\%$ & $\mathrm{f}$ & $\%$ & $\mathrm{f}$ & $\%$ & $\mathrm{f}$ & $\%$ \\
\hline Healthy foot & 16 & 53.3 & 17 & 77.3 & 9 & 69.2 & 19 & 82.6 \\
\hline $\begin{array}{l}\text { Pes planus } \\
1^{\text {st }} \text { degree }\end{array}$ & 4 & 13.3 & 4 & 18.2 & 3 & 23.1 & 3 & 13.0 \\
\hline $\begin{array}{l}\text { Pes planus } \\
2^{\text {nd }} \text { degree }\end{array}$ & 3 & 10.0 & 1 & 4.5 & 1 & 7.7 & 0 & 0 \\
\hline $\begin{array}{l}\text { Pes planus } \\
3^{\text {rd }} \text { degree }\end{array}$ & 4 & 13.3 & 0 & 0 & 0 & 0 & 0 & 0 \\
\hline $\begin{array}{l}\text { Pes cavus } \\
1^{\text {st }} \text { degree }\end{array}$ & 3 & 10.0 & 0 & 0 & 0 & 0 & 0 & 0 \\
\hline $\begin{array}{l}\text { Pes cavus } \\
2^{\text {nd }} \text { degree }\end{array}$ & 0 & 0 & 0 & 0 & 0 & 0 & 1 & 4.3 \\
\hline $\begin{array}{l}\text { Pes cavus } \\
3^{\text {rd }} \text { degree }\end{array}$ & 0 & 0 & 0 & 0 & 0 & 0 & 0 & 0 \\
\hline
\end{tabular}

$f=$ frequency

Table 4. Foot deformity frequencies in girls in 2005

\begin{tabular}{|l|l|l|l|l|l|l|l|l|l|}
\hline & $1^{\text {st }}$ grade & \multicolumn{2}{l|}{$2^{\text {nd }}$ grade } & \multicolumn{2}{|l|}{$3^{\text {rd }}$ grade } & \multicolumn{2}{|l|}{$4^{\text {th }}$ grade } \\
\cline { 2 - 10 } & $\mathrm{f}$ & $\%$ & $\mathrm{f}$ & $\%$ & $\mathrm{f}$ & $\%$ & $\mathrm{f}$ & $\%$ \\
\hline Healthy foot & 23 & 85.2 & 20 & 80.0 & 15 & 75.0 & 19 & 90.5 \\
\hline $\begin{array}{l}\text { Pes planus } \\
1^{\text {st }} \text { degree }\end{array}$ & 1 & 3.7 & 1 & 4.0 & 3 & 15.0 & 1 & 4.8 \\
\hline $\begin{array}{l}\text { Pes planus } \\
2^{\text {nd }} \text { degree }\end{array}$ & 2 & 7.4 & 1 & 4.0 & 0 & 0 & 0 & 0 \\
\hline $\begin{array}{l}\text { Pes planus } \\
3^{\text {rd }} \text { degree }\end{array}$ & 0 & 0 & 0 & 0 & 0 & 0 & 1 & 4.8 \\
\hline $\begin{array}{l}\text { Pes cavus } \\
1^{\text {st }} \text { degree }\end{array}$ & 0 & 0 & 3 & 12.0 & 2 & 10.0 & 0 & 0 \\
\hline $\begin{array}{l}\text { Pes cavus } \\
2^{\text {nd }} \text { degree }\end{array}$ & 0 & 0 & 0 & 0 & 0 & 0 & 0 & 0 \\
\hline $\begin{array}{l}\text { Pes cavus } \\
3^{\text {rd }} \text { degree }\end{array}$ & 1 & 3.7 & 0 & 0 & 0 & 0 & 0 & 0 \\
\hline
\end{tabular}

$\mathrm{f}=$ frequency

are studies that confirm a higher rate of deformity than normal feet at this age, with $59 \%$ in children aged $7-12^{21}, 50 \%-60 \%{ }^{16}$, and $60 \%-66 \%{ }^{17}$. Nevertheless, a significantly smaller number of deformities in children of this age can be observed when compared to preschool children. Therefore, the results of this research are consistent with the results that show how the frequency of some of the emerging forms of flat foot decreases with aging. Evans ${ }^{22}$ found 31 flat foot cases in
Table 5. Foot deformity frequencies in boys in 2011

\begin{tabular}{|l|l|l|l|l|l|l|l|l|l|}
\hline & \multicolumn{2}{|l|}{$1^{\text {st }}$ grade } & \multicolumn{2}{l|}{$2^{\text {nd }}$ grade } & \multicolumn{2}{|l|}{$3^{\text {rd }}$ grade } & \multicolumn{2}{|l|}{$4^{\text {th }}$ grade } \\
\cline { 2 - 10 } & $\mathrm{f}$ & $\%$ & $\mathrm{f}$ & $\%$ & $\mathrm{f}$ & $\%$ & $\mathrm{f}$ & $\%$ \\
\hline Healthy foot & 16 & 84.2 & 24 & 80.0 & 24 & 85.7 & 29 & 64.4 \\
\hline $\begin{array}{l}\text { Pes planus } \\
1^{\text {st }} \text { degree }\end{array}$ & 2 & 10.5 & 4 & 13.3 & 3 & 10.7 & 10 & 22.2 \\
\hline $\begin{array}{l}\text { Pes planus } \\
2^{\text {nd }} \text { degree }\end{array}$ & 0 & 0 & 1 & 3.3 & 1 & 3.6 & 4 & 8.9 \\
\hline $\begin{array}{l}\text { Pes planus } \\
3^{\text {rd }} \text { degree }\end{array}$ & 1 & 5.3 & 0 & 0 & 0 & 0 & 0 & 0 \\
\hline $\begin{array}{l}\text { Pes cavus } \\
1^{\text {st }} \text { degree }\end{array}$ & 0 & 0 & 1 & 3.3 & 0 & 0 & 2 & 4.4 \\
\hline $\begin{array}{l}\text { Pes cavus } \\
2^{\text {nd }} \text { degree }\end{array}$ & 0 & 0 & 0 & 0 & 0 & 0 & 0 & 0 \\
\hline $\begin{array}{l}\text { Pes cavus } \\
3^{\text {rd }} \text { degree }\end{array}$ & 0 & 0 & 0 & 0 & 0 & 0 & 0 & 0 \\
\hline
\end{tabular}

$f=$ frequency

Table 6. Foot deformity frequencies in girls in 2011

\begin{tabular}{|l|l|l|l|l|l|l|l|l|l|}
\hline \multirow{2}{*}{} & $1^{\text {st }}$ grade & \multicolumn{2}{l|}{$2^{\text {nd }}$ grade } & \multicolumn{2}{|l|}{$3^{\text {rd }}$ grade } & \multicolumn{2}{|l|}{$4^{\text {th }}$ grade } \\
\cline { 2 - 10 } & $\mathrm{f}$ & $\%$ & $\mathrm{f}$ & $\%$ & $\mathrm{f}$ & $\%$ & $\mathrm{f}$ & $\%$ \\
\hline Healthy foot & 21 & 72.4 & 18 & 75.0 & 23 & 79.3 & 31 & 75.6 \\
\hline $\begin{array}{l}\text { Pes planus } \\
1^{\text {st }} \text { degree }\end{array}$ & 5 & 17.2 & 4 & 16.7 & 4 & 13.8 & 4 & 9.8 \\
\hline $\begin{array}{l}\text { Pes planus } \\
2^{\text {nd }} \text { degree }\end{array}$ & 3 & 10.3 & 1 & 4.2 & 1 & 3.4 & 1 & 2.4 \\
\hline $\begin{array}{l}\text { Pes planus } \\
3^{\text {rd }} \text { degree }\end{array}$ & 0 & 0 & 0 & 0 & 0 & 0 & 0 & 0 \\
\hline $\begin{array}{l}\text { Pes cavus } \\
1^{\text {st }} \text { degree }\end{array}$ & 0 & 0 & 1 & 4.2 & 1 & 3.4 & 3 & 7.3 \\
\hline $\begin{array}{l}\text { Pes cavus } \\
2^{\text {nd }} \text { degree }\end{array}$ & 0 & 0 & 0 & 0 & 0 & 0 & 1 & 2.4 \\
\hline $\begin{array}{l}\text { Pes cavus } \\
3^{\text {rd }} \text { degree }\end{array}$ & 0 & 0 & 0 & 0 & 0 & 0 & 0 & 0 \\
\hline
\end{tabular}

$\mathrm{f}=$ frequency

a total of 140 (22\%) measured children aged 7-10. Sadeghi-Demneh et al. ${ }^{23}$ report on only $17 \%$ of flat foot at the age of 7-14. Mikić et al. ${ }^{14}$ report on up to $68 \%$ of normal feet in children aged 8-9, and $\mathrm{El}$ et al. ${ }^{15}$ on nearly $84 \%$ of healthy feet in children of the mean age of 9.2 years. Likewise noticeable was the decrease, although not statistically significant, of foot deformity while growing-up from elementary school $1^{\text {st }}$ to $4^{\text {th }}$ grade in both boys and girls. 
The only increase in deformity was observed in boys measured in 2011, with normal feet falling in percentage from $84 \%$ to $64 \%$ of cases. It can be concluded that the age and foot development play a significant role in the occurrence of deformities. In other words, deviations from normal values are more noticeable in younger children ${ }^{24-27}$.

In our study, no difference was found between subjects from different generations, i.e. between the children measured in 2005 and 2011. The frequency of healthy feet in both generations ranged around 76\% and there was no statistically significant difference in frequencies $\left(\chi^{2}=8.48 ; \mathrm{p}=0.21\right)$. The same applied to boys and girls measured in 2005 and 2011, although in 2011, a slightly higher frequency of healthy feet was evident in boys as compared to girls (Table 1). An apparently short period between the two measurements was not sufficient to cause significant anatomic changes caused by lifestyle.

Likewise, no gender differences were observed either in a single measurement or at any age. These results are opposed to other studies suggesting that boys are more inclined to foot deformities and that the incidence is more noticeable in male gender. Thus, Chen et al..$^{25}$ report on the $35 \%$ incidence in boys and $20 \%$ in girls aged 5-13. There are literature reports on gender differences in preschool children ${ }^{21,24-28}$, as well as in children aged $7-14^{23}$, whereas Hernandez et al. did not observe significant gender differences in the frequency of deformity in children aged 5-929.

\section{Conclusion}

Although foot deformities are considered to be one of the most common postural deformities, this research, conducted in a sample of $4261^{\text {st }}$ to $4^{\text {th }}$ grade primary schoolchildren, indicated that the largest number of subjects had no noticeable foot deformities, flat foot particularly. Likewise, there were no gender differences in the occurrence of flat foot and no differences in the incidence between children measured in 2005 and 2011. Obviously, gender does not play a significant role in the frequency of deformities, and the period of only six years between the measurements was insufficient to observe any significant anatomic changes in the feet of elementary school children. However, due to the problems that foot deformities could cause, it is necessary to continue monitoring foot arches in order to intervene in a timely manner and prevent the occurrence of deformities by appropriate therapeutic procedures.

\section{Acknowledgments}

The authors wish to thank the masters of primary education Ana Kolar and Aleksandar Ugarčić for their conscientious work performed when collecting the samples.

\section{References}

1. Ruszkowski I, Keros P, Ziger T. Plosnato stopalo/pes planus. Medicinski fakultet Sveučilišta u Zagrebu: Zagreb; 1994. (in Croatian)

2. Oatis CA. Kinesiology - The Mechanics and Pathomechanics of Human Movement. Baltimore: Lippincott Williams \& Wilkins: Wolters Kluwer Business; 2009.

3. Kapandji IA. The Physiology of the Joints. The Lower Limb. $6^{\text {th }}$ edn. Vol 2. Edinburgh, London, New York, Oxford, Philadelphia, St. Louis, Sydney, Toronto: Churchill Livingstone; 2010.

4. Franco AH. Pes cavus and pes planus. Phys Ther. 1987;67: 688-4.

5. Vnuk V. Kućni liječnik dijagnostičar. Zagreb: Alfa; 1988. (in Croatian)

6. Staheli LT, Chew DE, Corbett M. The longitudinal arch. J Bone Joint Surg. 1987;69(3):426-8.

7. Videmšek M, Klopčič P, Štihec J, Karpljuk D. The analysis of the arch of the foot in three-year-old children - a case of Ljubljana. Kinesiology. 2006;38(1):78-5.

8. Volpon JB. Footprint analysis during the growth period. J Pediatr Orthoped. 1994;14:83-5. doi: 10.1097/01241398-19940 1000-00017

9. Abdel-Fattah MM, Hassanin MM, Felembane FA, Nassaane MT. Flat foot among Saudi Arabian army recruits: prevalence and risk factors. E Mediterr Health J. 2006;12(1-2):211-7.

10. Mosca VS. Flexible flatfoot in children and adolescents.J Child Orth. 2010;4(2):107-21. doi: 10.1007/s11832-010-0239-9

11. Garcia-Rodriguez A, Martin-Jimenez F, Carnero-Var M, Gomez-Garcia E, Gomez-Aracena J, Fernandez-Crehuet J. Flexible flat feet in children: a real problem? Pediatrics. 1999; 103(6):1-3.

12. Rose GK. Flat feet in children. Br Med J. 1990;301:1330-1.

13. Skowron N, Malak R, Mojs E, Samborski W. Foot arch condition in comparison with the muscular balance of lower limbs in children at school age of 6-14 years. J Med Sci. 2016;84(2): 85-9.

14. Mikić B, Hodžić Z, Gerdijan N. Bratovčić V. Analiza statusa stopala učenika uzrasta 8 do 9 godina. Sport Log. 2010;8 (14-15):30-4. (in Croatian) 
15. El O, Akcali O, Kaner B, Kosay C, Arslan Y, Soylev S, et al. Flexible flatfoot and related factors in primary school children: a report of a screening study. Rheumatol Int. 2006;26:1050-3. doi: 10.1007/s00296-006-0128-1

16. Janković A, Ilić D, Đurić S. Detection of feet status in football school participants aged 11 to 13. Res Kinesiol. 2014;42(2): 134-9.

17. Kendic S, Skender N, Catovic A, Celes N, Dupljak I, Catovic $\mathrm{S}$. Frequency of feet deformities in pupils attending junior grades of elementary school. Bosnian J Basic Med. 2007;7 (3):226-30.

18. Rose GA, Welton EA, Marshall T. The diagnosis of flat foot in the child. J Bone Joint Surg. 1985;67(1):71- 8.

19. Gilmour JC, Burns Y. The measurement of the medial longitudinal arch in children. Foot Ankle Int. 2001;22(6):493-8.

20. Cvjetičanin M. Priručnik o stopalu. Samobor: TIP “A. G. Matoš", 1993. (in Croatian)

21. Chang JH, Wang SH, Kuo CL, Shen HS, Hong YW, Lin LC. Prevalence of flexible flatfoot in Taiwanese school-aged children in relation to obesity, gender, and age. Eur J Pediatr. 2010;169:447-2. doi: 10.1007/s00431-009-1050-9

22. Evans AM. The paediatric flat foot and general anthropometry in 140 Australian school children aged 7-10 years. J Foot Ankle Res. 2011;4(12):1-8. doi: 10.1186/1757-1146-4-12
23. Sadeghi-Demneh E, Jafarian F, Melvin JMA, Azadinia, Shamsi F, Jafarpishe M. Flatfoot in school-age children prevalence and associated factors. Foot Ankle Spec. 2015;8(3):186-3. doi: $10.1177 / 1938640015578520$

24. Pfeiffer M, Kotz R, Ledl T, Hauser G, Sluga M. Prevalence of flat foot in preschool-aged children. Pediatrics, 2006;118 (2):634-9. doi: 10.1542/peds.2005-2126

25. Chen JP, Chung MJ, Wang MJ. Flatfoot prevalence and foot dimensions of 5- to 13-year-old children in Taiwan. Foot Ankle Int. 2009;30(4):326-2. doi: 10.3113/FAI.2009.0326

26. Chen KC, Yeh CJ, Tung LC, Yang JF, Yang SF, Wang CH. Relevant factors influencing flatfoot in preschool-aged children. Eur J Pediatr. 2011;170:931-6. doi: 10.1007/s00431-010-1380-7

27. Enrrique VA, Serrano Sánchez RF, Correa Posadaad J R, Molano AC, Guevara OA. Prevalence of flatfoot in school between 3 and 10 years. Study of two different populations geographically and socially. Colomb Med. 2012;43(2):142-7.

28. Mickle KJ, Steele JR, Munro BJ. The foot structure of preschool children moderated by gender? J Pediatr Orthoped. 2008;28(5):593-6. doi: 10.1097/BPO.0b013e318173f782

29. Hernandez AJ, Kimura JK, Ferreira Larayam MH, Fávaro E. Calculation of Staheli's plantar arch index and prevalence of flat feet: a study with 100 children aged 5-9 years. Acta Ortop Bras. 2007;15(2):68-71. doi: $10.1590 / \mathrm{S} 1413-78522007000200001$

Sažetak

\section{UČESTALOST DEFORMITETA STOPALA U DJECE MLAĐE ŠKOLSKE DOBI U SLAVONIJI}

\section{Bogut, Ž. Popović, Z. Tomac, V. Matijevići i G. Radmilović}

Cilj istraživanja bio je odrediti pojavu deformacije stopala djece u urbanoj sredini, kao i moguće razlike prema dobi i spolu primjenom grafičke i kutne metode za mjerenje deformacije stopala. Uzorak ispitanika obuhvatio je 426 djece 1 . do 4. razreda, od čega je 181 (88 dječaka i 93 djevojčice) ispitano u 2005. godini, a 244 djece (122 dječaka i 123 djevojčice) u 2011. godini. Rezultati su pokazali da najveći broj djece nije imao vidljive deformacija stopala, osobito spušteno stopalo. Nisu pronađene statistički značajne razlike u visini lukova stopala između dječaka i djevojčica niti između dvije godine mjerenja. Zbog ozbiljnih medicinskih problema koje mogu uzrokovati deformacije stopala kao što je spušteno stopalo potrebno je kontinuirano mjeriti lukove stopala djece mlađe školske dobi kako bi se pravodobno moglo intervenirati i spriječiti nastanak deformacija odgovarajućim terapeutskim postupcima.

Ključne riječi: Stopalo, deformiteti; Stopalo, ravno; Dijete; Urbana populacija; Hrvatska 